\title{
Effect of islet activating protein on glucose tolerance, insulin secretion and insulin responsiveness in the NZO mouse
}

\author{
C.A.Re, M.C. Veroni and R.G. Larkins \\ Departments of Medicine, University of Melbourne, Royal Melbourne Hospital and Repatriation General Hospital, Victoria, Australia
}

\begin{abstract}
Summary. The effect of islet activating protein on glucose tolerance, insulin secretion and insulin responsiveness was studied in the NZO mouse, a model of non-insulin dependent diabetes and obesity. A single IV injection of $5 \mathrm{ng} / \mathrm{g}$ body weight islet activating protein markedly lowered plasma glucose and the glucose response to IP glucose administration, measured 5 days later (mean \pm SEM, plasma glucose levels $0,10,30$ and $60 \mathrm{~min}$ after glucose $6.0 \pm 0.9,14.6 \pm 1.3,14.1 \pm 1.3$ and $13.2 \pm$ $1.7 \mathrm{mmol} / 1$ in islet activating protein-treated NZO mice versus $12.8 \pm 1.6,27.8 \pm 3.4,34.7 \pm 4.1,39.1 \pm 3.8 \mathrm{mmol} / 1$ in carriertreated NZO mice). There was no difference in fasting plasma insulin levels between islet activating protein and carrier-treated mice. No response of plasma insulin to glucose occurred in the carrier-treated mice, but a highly significant insulin response to glucose was seen in the islet activating protein-treated mice. The in vitro responsiveness of pancreatic islets of is-
\end{abstract}

let activating protein-treated NZO mice to glucose was improved, and the inhibitory effect of adrenaline on insulin secretion was reduced. The in vivo hypoglycaemic response to exogenous insulin was not improved by islet activating protein and a demonstrated defect in the insulin sensitivity and responsiveness of glucose utilization by isolated soleus muscle was not reversed by islet activating protein treatment. It is concluded that islet activating protein is highly effective in improving glucose tolerance and insulin secretion in NZO mice, and that the improvement in glucose tolerance occurs without demonstrable improvement in the responsiveness to exogenous insulin or sensitivity of soleus muscle to insulin.

Key words: islet activating protein, NZO mice, insulin secretion, insulin responsiveness, soleus muscle.
Islet activating protein (IAP) is a protein of molecular weight 77000 daltons purified from culture medium of Bordetella pertussis [1]. A single injection of IAP has been shown to increase pancreatic insulin secretion and improve glucose tolerance for up to 6 weeks in normal and diabetic rats [2,3], the KK strain of diabetic mice [4] and alloxan-treated diabetic dogs [5]. It also increases insulin secretion in cultured rat [6] and human [7] islets and decreases the inhibitory action of adrenaline on islet insulin secretion [6,8]. Recent investigation has shown that IAP modifies receptor coupling to adenylate cyclase [9] by ADP-ribosylation of one of the subunits of the guanine nucleotide regulatory component of the adenylate cyclase system [10]. In addition, an action on endogenous lipid associated calcium ionophoretic activity has been demonstrated [11] presumably accounting for increased transmembrane calcium fluxes [6]. In view of the ubiquitous nature of cyclic adenosine3',5'-monophosphate (cyclic AMP) and intracellular calcium ion as regulators of cell function, it is reasonable to assume that the actions of IAP are not confined to the pancreatic $\beta$ cell. Indeed, IAP has been shown to cause leucocytosis and histamine sensitivity in mice [2], to affect receptor mediated cyclic AMP accumulation in cardiac cells [12] and cultured rat glioma cells [10] and to stimulate glucagon secretion [13].

In non-insulin-dependent diabetes there is evidence that insulin resistance contributes to the glucose intolerance [14-18]. The relative roles of impaired insulin secretion and of insulin resistance in the pathogenesis of non-insulin-dependent diabetes is debatable. A major aim of the present study was to see whether an agent presumed to act only at the level of insulin secretion, could substantially improve glucose tolerance in a laboratory model of non-insulin dependent diabetes mellitus.

The NZO mouse is characterized by obesity, glucose intolerance, insulin resistance, basal hyperinsulinaemia [19-21] and a poor insulin secretory response to glucose [22-26]. It is thus an appropriate model for non-insulindependent diabetes mellitus. In the present study, the effects of IAP on glucose tolerance, insulin secretion 
and insulin action were studied in the NZO mouse. These in vivo studies were combined with studies of the effect of IAP administration on insulin secretion from isolated islets of NZO mice, and on basal and insulin stimulated glucose utilization and glycogen synthesis in isolated soleus muscle from NZO and control mice.

\section{Materials and methods}

Female NZO mice were purchased from the colony maintained at the Walter and Eliza Hall Institute, Parkville, Victoria, Australia. A colony of random bred white mice, originally derived from the CSIRO Animal Research Laboratories, Parkville, Victoria, was used as the non-diabetic control strain. All mice were fed ad libitum on standard commercial laboratory chow and water, and studied between the ages of 3 and 6 months.

\section{Glucose tolerance test}

Mice were fasted overnight, then anaesthetized with pentobarbitone sodium (Nembutal, Abbott Laboratories, Sydney, Australia) $40 \mu \mathrm{g} / \mathrm{g}$ body weight, half given IP and half SC. Glucose was injected IP in a dose of $1 \mathrm{mg} / \mathrm{g}$ body weight as a $25 \%$ solution in water. Blood $(150 \mu \mathrm{l})$ was collected from the retroorbital sinus using heparinized capillary tubes before and at 10,30 and $60 \mathrm{~min}$ after the glucose injection. It was transferred immediately to iced, heparinized microcentrifuge tubes, and at the completion of the test, centrifuged in a microcentrifuge (Beckman Instruments, Fullerton, California) and the plasma stored at $-20{ }^{\circ} \mathrm{C}$ until assay.

\section{Insulin tolerance test}

Non-fasted mice were injected IV with $0.2 \mathrm{mU} / \mathrm{g}$ of highly purified soluble porcine insulin (Actrapid, Novo, Bagsvaerd, Denmark). Blood $(100 \mu \mathrm{l})$ was collected before and at 5, 10,15 and $20 \mathrm{~min}$ after the insulin injection and plasma separated and stored as described above. To facilitate comparison between groups, the fall in plasma glucose at each time point after the insulin injection was expressed as a percentage of the initial plasma glucose.

\section{Insulin secretion in vitro}

Islets were isolated from the pancreas of non-fasting NZO mice using collagenase digestion as described previously [26]. The islets were incubated in groups of five in Krebs Ringer bicarbonate buffer supplemented with bovine serum albumin $(350 \mathrm{mg} / 100 \mathrm{ml}$, Commonwealth Serum Laboratories, Parkville, Victoria, Australia) and N-2-hydroxy ethylpiperazine-2-ethanesulphonic acid $(10 \mathrm{mmol} / 1$, Hepes, Sigma Chemicals, St. Louis, Missouri), $\mathrm{pH}$ 7.4. All islets were incubated initially for $30 \mathrm{~min}$ in glucose $(3.3 \mathrm{mmol} / \mathrm{l})$, the supernatant discarded, the islets washed twice in Krebs Ringer bicarbonate buffer, glucose $(3.3 \mathrm{mmol} / \mathrm{l})$ and then incubated for a final period of $20 \mathrm{~min}$ at glucose concentrations of $3.3,8.4$ and $16.7 \mathrm{mmol} / 1$. The low and high glucose concentrations were tested with and without adrenaline $\left(10^{-6} \mathrm{~mol} / 1\right)$. Finally, the supernatant was aspirated and stored at $-20^{\circ} \mathrm{C}$.

\section{Islet insulin content}

Islets were isolated from non-fasted NZO mice as described above, homogenized at $4{ }^{\circ} \mathrm{C}$ with the addition of sucrose containing medium (final sucrose concentration $150 \mathrm{mmol} / \mathrm{l}$ ), as described previously [27]. The homogenates were diluted $1: 1000$ and assayed for insulin as described previously [26].
Glucose utilization and glycogen synthesis by isolated soleus muscle

Soleus muscles were dissected from mice killed by cervical dislocation, taking care to avoid damage to muscle fibres. The muscles were tied by cotton to small metal holders to produce constant, slight tension; they were pre-incubated individually for two $15 \mathrm{~min}$ periods in $1.5 \mathrm{ml}$ Krebs Ringer bicarbonate medium supplemented with $2 \%$ defatted bovine serum albumin and glucose $(5 \mathrm{mmol} / \mathrm{l})$ at $37^{\circ} \mathrm{C}$. After washing, they were incubated for a further hour at $37^{\circ} \mathrm{C}$ in the same medium with the addition of the indicated concentration of porcine insulin (Actrapid), and $1 \mu \mathrm{Ci} /$ vial of $\mathrm{D}-\left[5-{ }^{3} \mathrm{H}\right]$ glucose $(10-20 \mathrm{Ci} /$ mmol, Radiochemical Centre, Amersham UK). Each vial was continuously gassed with $\mathrm{O}_{2}: \mathrm{CO}_{2}(95 \%: 5 \%)$. At the end of the incubation period, $200 \mu \mathrm{l}$ of incubation medium was transferred to plastic centre wells suspended inside a $20 \mathrm{ml}$ scintillation vial containing $300 \mathrm{mg}$ anhydrous $\mathrm{CaCl}_{2}$. A strip of filter paper was inserted into the wells to increase the surface area for evaporation of the liquid. The vials were incubated at $37{ }^{\circ} \mathrm{C}$ overnight, the wells removed, $1 \mathrm{ml}$ of water was added to the vial to dissolve the $\mathrm{CaCl}_{2}$, scintillant added and ${ }^{3} \mathrm{H}_{2} \mathrm{O}$ counted in a liquid scintillation spectrometer (Packard Instruments, Downers Grove, Illinois, USA).

At the end of the incubation, the muscle was hydrolysed in $5.4 \mathrm{~mol} / 1 \mathrm{KOH}(0.5 \mathrm{ml})$ at $80^{\circ} \mathrm{C}$ for $20 \mathrm{~min}$. After cooling to $4{ }^{\circ} \mathrm{C}$, $10 \mathrm{mg}$ carrier glycogen was added, and the glycogen precipitated with saturated $\mathrm{Na}_{2} \mathrm{SO}_{4}(0.2 \mathrm{ml})$ and $95 \%$ ethanol $(1.6 \mathrm{ml})$. The samples were placed at $-20{ }^{\circ} \mathrm{C}$ for $1 \mathrm{~h}$, centrifuged for $20 \mathrm{~min}$ at $3000 \mathrm{rev} / \mathrm{min}$, and the supernatants discarded. The precipitates were resuspended in water, scintillant added, and ${ }^{3} \mathrm{H}$-glycogen counted in a liquid scintillation spectrometer.

Results are expressed as nmol of glucose utilised or converted to glycogen per mg wet weight of muscle.

\section{Islet activating protein treatment}

IAP was kindly provided by Dr M. Yajima, Kakenyaku Kako, Otsu, Shiga, Japan, and it was dissolved initially as an $80 \mu \mathrm{g} / \mathrm{ml}$ solution in phosphate buffer containing urea ( $2 \mathrm{~mol} / 1)$, and diluted with normal saline prior to injection. The solution was used within 3 weeks; it was injected IV into the tail vein of non-fasted mice in a dose of $5 \mathrm{ng} / \mathrm{g}$ body weight. Randomly chosen mice received an IV injection of carrier alone. The appropriate in vivo tests were performed 5 days after IAP or carrier injection, and the in vitro tests of insulin secretion and muscle insulin responsiveness were performed 7 days after IAP injection. IAP treatment did not cause alteration of body weight or apparent health of the mice.

\section{Assays}

Plasma immunoreactive insulin was assayed using a double antibody technique on 5-10 $\mu$ l plasma samples [29] and guinea pig anti-insulin serum as the first antibody (Wellcome Laboratories, Beckenham, Kent, UK). To achieve sufficient sensitivity, an incubation volume of $110 \mu l$ and microcentrifuge tubes (Beckman Instruments) were used. A 1 day pre-incubation at $4{ }^{\circ} \mathrm{C}$ was used before the addition of ${ }^{125}$ I-labelled porcine insulin tracer (prepared by the method of Hunter and Greenwood [30]). Separation of antibody bound from free tracer was performed with anti-guinea pig serum (Wellcome Laboratories) after a further $24 \mathrm{~h}$ incubation at $4{ }^{\circ} \mathrm{C}$. The intra-assay coefficient of variation was $4.6 \%$ at an insulin concentration of $5 \mathrm{ng} / \mathrm{ml}$, and the interassay coefficient of variation was $8.8 \%$ at $2 \mathrm{ng} / \mathrm{ml}$. Sensitivity (as defined by $10 \%$ displacement of insulin tracer by unlabelled insulin) was $0.25 \mathrm{ng} / \mathrm{ml}$ in a $10 \mu \mathrm{l}$ sample volume. The results were expressed in terms of mouse insulin standards (Novo, Bagsvaerd, Denmark). In the in vitro studies of insulin secretion, insulin was assayed as described previously [26].

Plasma glucose concentrations were determined by a glucose oxidase-peroxidase method, utilizing commercial reagents (Boehringer Mannheim, FRG). For plasma samples, $10 \mu \mathrm{l}$ of plasma were diluted $1: 11$ with distilled water prior to assay. 


\section{Statistical analyses}

The statistical significance of differences between mean values was assessed by Student's t-test, paired or unpaired as appropriate. The plasma insulin responses to glucose were transformed by logarithmic conversion to achieve a normal distribution prior to this analysis.

\section{Results}

\section{Glucose tolerance and plasma insulin levels}

Carrier-treated NZO mice had significantly higher plasma glucose before and at all time points following glucose injection (Fig.1) compared with carrier-treated control mice. IAP treatment markedly lowered plasma glucose levels at all time points in both the NZO and control mice $(p<0.001)$.

Fasting plasma insulin levels following carrier injection were significantly higher in NZO mice than in the control mice $(p<0.001)$. However, there was no significant response of plasma insulin to IP glucose in the carrier-injected NZO mice, compared with a greater than fivefold rise in the control mice (Fig.1). In the control strain, plasma insulin levels, at fasting and $10 \mathrm{~min}$ after glucose treatment, were the same in IAP-treated compared with carrier-treated mice, but subsequent values were significantly lower in IAP-treated mice. In the NZO strain, fasting insulin levels were unchanged after IAP treatment, but in contrast to carrier-treated mice a significant rise in plasma insulin following glucose administration was evident at all time points, despite the much smaller glycaemic stimulus in the IAP-treated mice.

\section{Insulin responsiveness in vivo}

Table 1 shows that IAP pretreatment enhanced the hypoglycaemic effect of IV insulin in the control mice, but the insulin resistance of the NZO mice was not altered by pretreatment with IAP.

\section{Insulin secretion in vitro in islets from $\mathrm{NZO}$ mice}

As has been shown previously [26], islets from NZO mice which had not received IAP showed high insulin secretion at low glucose concentration, no response to $8.4 \mathrm{mmol} / \mathrm{l}$ glucose, and only a slight response (1.6-fold in relation to the basal secretion) to $16.7 \mathrm{mmol} / 1$ glucose (Fig. 2). In contrast, islets from mice treated with IAP showed lower insulin secretion at $3.3 \mathrm{mmol} / 1$ glucose, but a significant increase in insulin secretion at $8.4 \mathrm{mmol} / 1$ glucose (1.6-fold), and a greater relative response to $16.7 \mathrm{mmol} / \mathrm{l}$ glucose ( 2.5 -fold) than was seen in islets from carrier-treated NZO mice. In addition, adrenaline completely abolished the response to $16.7 \mathrm{mmol} / 1$ glucose in the islets from the carrier-treated NZO mice, but did not prevent a significant response occurring in the islets from the IAP-treated mice. The
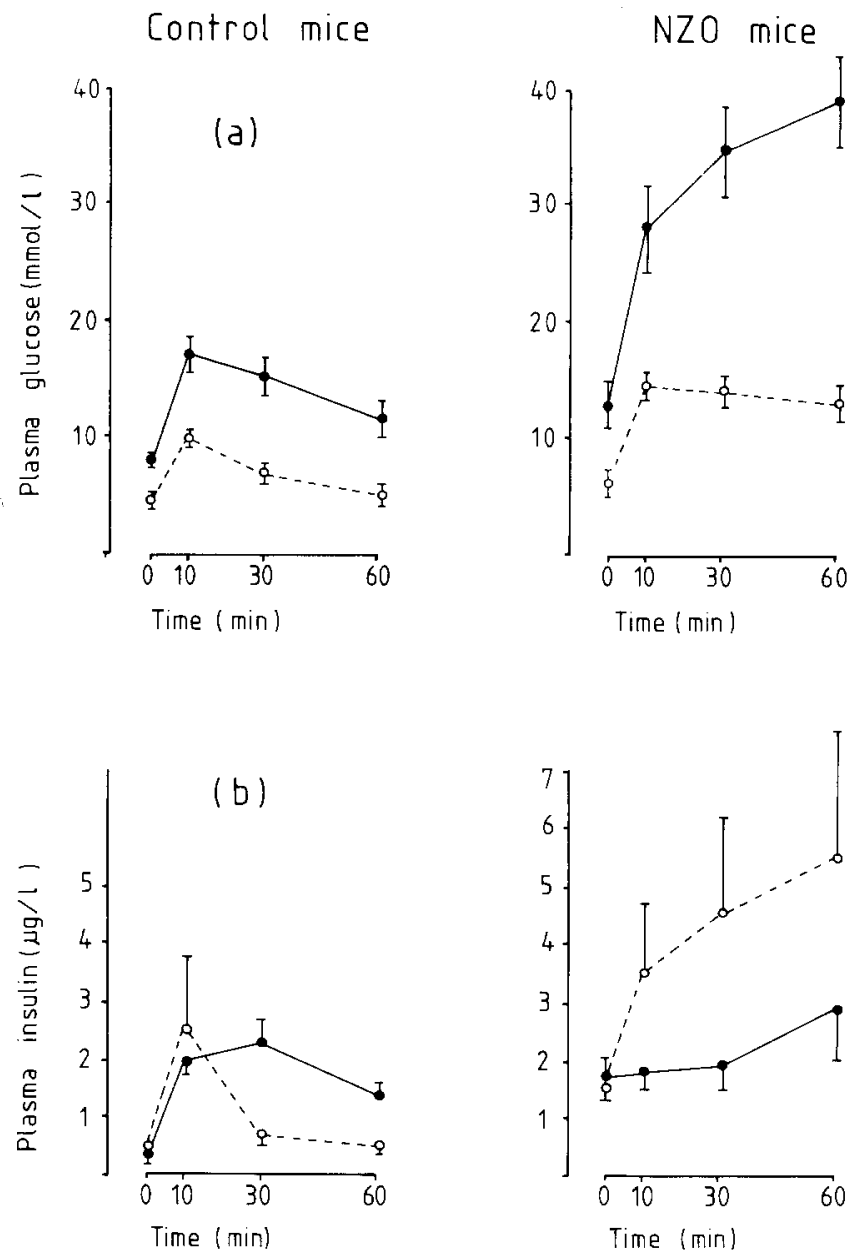

Fig. 1. Plasma glucose and insulin responses to $1 \mathrm{mg} / \mathrm{g}$ body weight glucose injected IP at time 0 in carrier $(-0)$ and IAP (O---O)-treated mice. Mean \pm SEM values are given for control mice $(n=16$, carrier) and IAP $(n=9)$ treatment; for NZO mice values are given for carrier $(n=10)$ and IAP $(n=12)$ treatment. For both control and NZO mice, plasma glucose values were significantly lower after IAP treatment at all time points $(p<0.001)$. Plasma insulin shows a significant rise in response to glucose by $10 \mathrm{~min}$ in the control mice treated with carrier or IAP, and in the NZO mice treated with IAP $(p<0.001)$, but there was no significant rise following glucose in the carrier-treated NZO mice

Table 1. The percentage fall in plasma glucose following IV insulin $(0.2 \mathrm{mU} / \mathrm{g}$ body weight $)$

\begin{tabular}{clrrrr}
\hline Mice & $\begin{array}{l}\text { Treat- } \\
\text { ment }\end{array}$ & \multicolumn{4}{l}{$\begin{array}{l}\text { Percentage fall in plasma glucose (min after } \\
\text { insulin) }\end{array}$} \\
\cline { 3 - 6 } & & $5 \mathrm{~min}$ & $10 \mathrm{~min}$ & $15 \mathrm{~min}$ & $20 \mathrm{~min}$ \\
\hline Control & Carrier & $15.2 \pm 7.1$ & $18.6 \pm 7.2$ & $9.5 \pm 4.8$ & $6.7 \pm 4.5$ \\
$(n=8)$ & IAP & $38.5 \pm 8.4^{\mathrm{a}}$ & $34.6 \pm 7.8$ & $31.8 \pm 7.4^{\mathrm{a}}$ & $27.0 \pm 6.6^{\mathrm{a}}$ \\
$\mathrm{NZO}$ & Carrier & $7.6 \pm 3.9$ & $7.4 \pm 4.5$ & $4.8 \pm 4.7$ & $4.8 \pm 4.8$ \\
$(n=8)$ & IAP & $3.8 \pm 2.0$ & $12.6 \pm 5.2$ & $4.3 \pm 0.7$ & $1.9 \pm 1.9$ \\
\hline
\end{tabular}

Results expressed as mean \pm SEM

${ }^{a} p<0.05$, IAP versus carrier-treated mice

average insulin content of islets from IAP-treated mice $(194 \pm 17 \mathrm{ng} /$ islet, mean $\pm \mathrm{SEM}$, assayed in 25 islets from each of five mice) did not differ from that of islets from carrier-treated mice ( $221 \pm 17 \mathrm{ng} /$ islet $)$. 


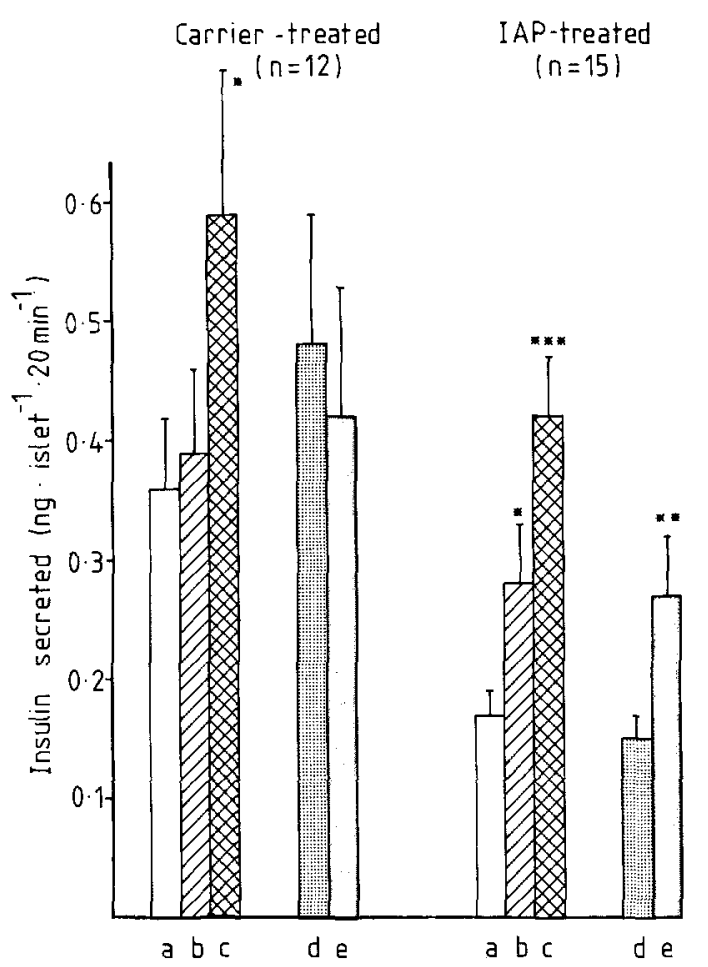

Fig. 2. Insulin release by isolated islets from NZO mice pretreated with carrier or IAP a $\square$ - glucose $3.3 \mathrm{mmol} / \mathrm{l}$, b $\square$ - glucose $8.4 \mathrm{mmol} / \mathrm{l}$, c - glucose $16.7 \mathrm{mmol} / \mathrm{l}, \mathrm{d} \square$ - glucose $3.3 \mathrm{mmol} /$ $1+$ adrenaline $10^{-6} \mathrm{~mol} / \mathrm{l}$, e $\square$ - glucose $16.7 \mathrm{mmol} / 1+$ adrenaline $10^{-6} \mathrm{~mol} / \mathrm{l}$. ${ }^{*} p<0.05,{ }^{* *} p<0.01,{ }^{* * *} p<0.001$ comparing $\mathrm{b}$ and $\mathrm{c}$ with $a$, and e with $\mathrm{d}$

Glucose utilization and glycogen synthesis by isolated soleus muscle

There was a marked impairment in glucose utilization in response to insulin in soleus muscle from carriertreated NZO mice compared with control mice (Fig. 3). A similar, less marked, trend was seen with glycogen synthesis. IAP pretreatment did not affect glucose utilization or glycogen synthesis in either control or NZO mice.

\section{Discussion}

This study has confirmed the potential of IAP as a therapeutic agent in diabetes mellitus. A single intravenous injection of $5 \mathrm{ng} / \mathrm{g}$ body weight greatly improved glucose tolerance in the NZO strain of obese hyperglycaemic mice when tested 5 days later. This effect was associated with a restoration of the sensitivity of the pancreatic $\beta$ cells to a hyperglycaemic stimulus and was demonstrable both in vivo and in isolated islets in vitro. The lower insulin secretion at $3.3 \mathrm{mmol} / 1$ glucose in islets from IAP-pretreated mice presumably was due to the lower glucose concentration to which they had been exposed in vivo prior to isolation. Although the abso-
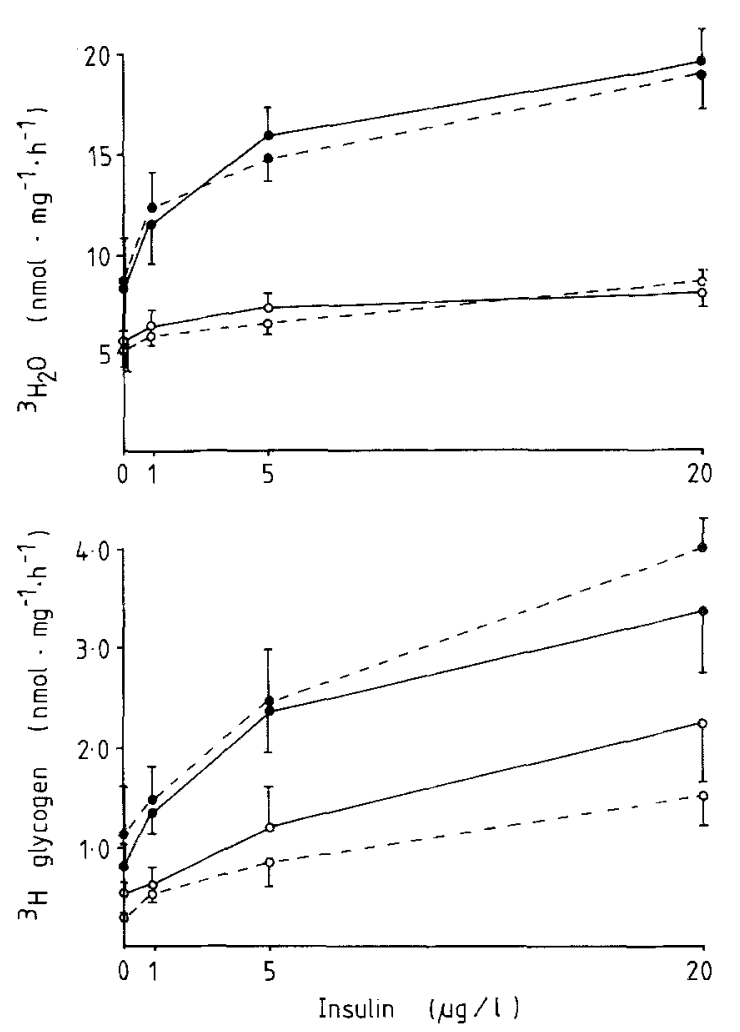

Fig. 3. Conversion of $\left[5-{ }^{3} \mathrm{H}\right]$-glucose to ${ }^{3} \mathrm{H}_{2} \mathrm{O}$ (top panel) and ${ }^{3} \mathrm{H}$ glycogen (bottom panel) by isolated soleus muscle from control mice treated with carrier (-O), control mice treated with IAP $(--)$ ), NZO mice treated with carrier $\left(O_{-}\right)$) and NZO mice treated with IAP $(O---O)$. Mean \pm SEM values from four separate muscles are given at each insulin concentration

lute magnitude of the insulin response of the isolated islets of the NZO mice was similar in IAP- and carriertreated mice, it is probably the sensitivity of the islets to glucose, rather than their absolute response, which is important in determining the insulin response to a glucose load in vivo. The sensitivity of the islets to glucose was clearly improved in islets from IAP-treated mice, which showed a significant secretory response to $8.4 \mathrm{mmol} / 1$ glucose, not seen in islets from carrier-treated mice. It might be suggested that the improved sensitivity of the pancreatic $\beta$ cells to a hyperglycaemic stimulus is a direct consequence of the reduction in the fasting plasma glucose. Although a contribution of this mechanism cannot be excluded, it should be noted that similar effects have been observed following direct exposure of islets to IAP in culture $[8,31]$. The characteristic blunting of the inhibitory effect of adrenaline on glucose-induced insulin secretion in vitro was seen also. The improvement in glucose tolerance in the control strain treated with IAP occurred without measurable changes in insulin levels. However, the same insulin levels were achieved at much lower glucose concentrations, showing that an enhancement of sensitivity of the $\beta$ cells to glucose had occurred following IAP in this strain also.

The improvement in glucose tolerance in the NZO 
mice following IAP pretreatment occurred without an improvement in the responsiveness to exogenous insulin in vivo. The hypoglycaemic effect of insulin in control mice was greater following IAP pretreatment, which could have been due to IAP pretreatment preventing suppression of endogenous insulin secretion by hypoglycaemia, or to an impairment of counter-regulatory mechanisms. However, as no effect of IAP pretreatment on the poor hypoglycaemic action of insulin in the NZO mouse was seen, the results support the idea that the improvement in glucose tolerance in the NZO mice is due to the effect of IAP on $\beta$ cell responsiveness to glucose. Lower fasting glucose levels were observed in both NZO and control mice which had been pretreated with IAP, despite similar fasting insulin levels. As there are many determinants of fasting plasma glucose, no deductions about insulin sensitivity can be made from the relationship between insulin and glucose in this situation. Similarly, trying to estimate insulin sensitivity or responsiveness by relating plasma glucose to plasma insulin directly during glucose tolerance testing has been shown to be potentially misleading [32].

Thus the validity of assessment of insulin sensitivity by either the measurement of blood glucose fall following a single bolus injection of insulin, or measurement of insulin to glucose ratios at given time points is questionable. The glucose clamp technique is still impractical in mice. For these reasons, insulin sensitivity of muscle was assessed in vitro in mice pretreated with carrier or IAP. A striking impairment in glucose utilization in response to insulin was observed in soleus muscle from carrier-treated NZO mice, as has been described previously for other strains of obese hyperglycaemic rodents $[28,33-36]$. IAP pretreatment had no effect on the impaired insulin sensitivity and responsiveness of soleus muscle.

As the NZO mouse is a model for non-insulin-dependent diabetes in man, it is significant that an agent, apparently acting largely at the level of the pancreatic $\beta$ cell, is able to produce a striking improvement in glucose tolerance. This improvement was achieved without exaggerating the basal hyperinsulinaemia. The results emphasize the significance of the defect in the pancreatic $\beta$ cell response to glucose in determining glucose intolerance in this animal model. They show also that changes in $\beta$ cell responsiveness and peripheral insulin sensitivity can be dissociated, and should be regarded as independent contributors to glucose intolerance.

Acknowledgements. The authors gratefully acknowledge the generous supply of the islet activating protein by Dr. M. Yajima, Kakenyaku Kako, Otsu, Shiga, Japan, and technical advice from Dr. M. Gould of Monash University, Clayton, Victoria. This work was supported by the National Health and Medical Research Council, Australia.

\section{References}

1. Yajima M, Hosoda K, Kanbayashi $Y$, Nakamura T, Nogimori $K$, Mizushima S, Nakase Y, Ui M (1978) Islet-activating protein in
Bordetella pertussis that potentiates insulin secretory responses of rats. Purification and characterization. J Biochem 83:295-303

2. Yajima M, Hosoda, Kanbayashi Y, Nakamura T, Takahashi I, Ui M (1978) Biological properties of islet-activating protein purified from the culture medium of Bordetella pertussis. J Biochem 83: $305-312$

3. Toyota T, Kakizaki M, Kimura K, Yajima M, Okamoto T, Ui M (1978) Islet-activating protein derived from the culture supernatant fluid of Bordetella pertussis: effect on spontaneous diabetic rats. Diabetologia 14: 319-323

4. Okamoto T, Itoh A, Yajima M, Ui M (1980) Improvement of diabetic symptoms of hereditary diabetic (KK) mice by a single injection with islet-activating protein. J Pharm Dyn 3: 470-477

5. Yoshida T, Nakamura Y, Nakano K, Kondo M (1981) Effect of islet-activating protein, purified from the culture medium of Bordetella pertussis, on the secretion of immunoreactive insulin and glucagon in normal, alloxan-treated, and depancreatized dogs. Diabetes 30: 430-434

6. Katada T, Ui M (1979) Islet-activating protein enhanced insulin secretion and cyclic AMP accumulation in pancreatic islets due to activation of native calcium ionophores. J Biol Chem 254: 469-479

7. Araki Y, Yoshida T, Nakamura N, Koyama K, Nakamura Y, Nakano K, Kondo K (1981) Effect of islet-activating protein upon insulin secretion from human pancreatic islets. Endocrinol Japon 28: $139-143$

8. Katada T, Ui M (1980) Slow interaction of islet-activating protein with pancreatic islets during primary culture to cause reversal of $\beta$-adrenergic inhibition of insulin secretion. J Biol Chem 255: 9580-9588

9. Katada T, Ui M (1981) Islet-activating protein. A modifier of receptor-mediated regulation of rat adenylate cyclase. J Biol Chem 256: 8310-8317

10. Katada T, Ui M (1982) ADP ribosylation of the specific membrane protein of $\mathrm{C} 6$ cells by islet-activating protein associated with modification of adenylate cyclase activity. J Biol Chem 257: 7210-7216

11. Dunlop ME, Larkins RG (1983) Enhanced glucose-induced insulin release and endogenous $\mathrm{Ca}^{2+}$ ionophoretic activity in neonatal rat islets following islet-activating protein. Biochem Biophys Res Commun 112: 684-692

12. Hazeki O, Ui M (1981) Modification by islet-activating protein of receptor-mediated regulation of cyclic AMP accumulation in isolated rat heart cells. J Biol Chem 256: 2856-2862

13. Kikkawa R, Haneda M, Hatanaka I, Shigeta Y, Ueno T, Okuno M (1981) Effect of islet-activating protein of Bordetella pertussis on glucagon release from mice isolated islets. Horm Metab Res 13: $713-714$

14. Reaven GM, Bernstein R, Davis B, Olefsky JM (1976) Nonketotic diabetes mellitus: insulin deficiency or insulin resistance? Am $\mathbf{J}$ Med 60: 80-88

15. Ginsberg H, Kimmerling G, Olefsky JM, Reaven GM (1976) Demonstration of insulin resistance in maturity onset diabetic patients with fasting hyperglycemia. J Clin Invest 55: 454-460

16. Nagulesparan M, Savage PJ, Mott DM, Johnson GC, Uger RH, Bennett PH (1980) Increased insulin resistance in obese, glucoseintolerant southwestern American Indians: evidence for a defect not explained by obesity. J Clin Endocrinol Metab 51: 739-743

17. Ginsberg H, Rayfield EJ (1981) Effect of insulin therapy on insulin resistance in type II diabetic subjects. Evidence for heterogeneity. Diabetes 30: 739-745

18. Olefsky JM (1981) Insulin resistance and insulin action. An in vitro and in vivo perspective. Diabetes $30: 148-162$

19. Bielschowsky M, Bielschowsky F (1956) The New Zealand strain of obese mice. Their response to stilboestrol and to insulin. Aust $\mathbf{J}$ Exp Biol Med Sci 34: 181-198

20. Sneyd JGT (1964) Pancreatic and serum insulin in the New Zealand strain of obese mice. J Endocrinol 28: 163-172

21. Crofford OB, Davis CK (1965) Growth characteristics, glucose tolerance and insulin sensitivity of New Zealand obese mice. Metabolism 14: 271-280 
22. Larkins RG, Martin FIR (1972) Selective defect in insulin release in one form of spontaneous laboratory diabetes. Nature 235: $86-88$

23. Larkins RG (1973) Defective insulin secretory response to glucose in the New Zealand obese mouse. Improvement with restricted diet. Diabetes 22: 251-255

24. Larkins RG (1973) Defective insulin secretion in the NZO mouse: in vitro studies. Endocrinology 93: 1052-1056

25. Cameron DP, Opat F, Insch S (1974) Studies of immunoreactive insulin secretion in NZO mice in vivo. Diabetologia 10: 649-654

26. Larkins RG, Simeonova L, Veroni MC (1980) Glucose utilization in relation to insulin secretion in $\mathrm{NZO}$ and $\mathrm{C} 57 \mathrm{Bl}$ mouse islets. Endocrinology 107: 1634-1638

27. Dunlop M, Larkins RG, Court JM (1982) The effect of maternal caffeine ingestion on pancreatic function in the neonatal rat. Diabetologia $23: 354-358$

28. Le Marchand-Brustel Y, Jeanrenaud B, Freychet P (1978) Insulin binding and effects in isolated soleus muscle of lean and obese mice. Am J Physiol 234: E348-E358

29. Cameron DP, Stauffacher W, Amherdt M, Orci L, Renold AE (1972) Kinetics of immunoreactive insulin release in obese hyperglycemic laboratory rodents. Endocrinology 92: 257-264

30. Hunter WM, Greenwood FC (1962) Preparation of ${ }^{131}$ I-labelled human growth hormone. Nature 194: 495-496

31. Dunlop ME, Larkins RG (1983) Enhanced glucose-induced insulin release and endogenous $\mathrm{Ca}^{2+}$ ionophoretic activity in neonatal rat islets following islet-activating protein. Biochem Biophys Res Commun 112: 684-692
32. Reaven GM, Moore J, Greenfield M (1983) Quantification of insulin secretion and in vivo insulin action in non-obese and moderately obese individuals with normal glucose tolerance. Diabetes 32: $600-604$

33. Cuendet GS, Loten EG, Jeanrenaud B, Renold AE (1976) Decreased basal, non-insulin-stimulated glucose uptake and metabolism by skeletal soleus muscle isolated from obese-hyperglycemic (ob/ob) mice. J Clin Invest 58: 1078-1088

34. Le Marchand-Brustel Y, Jeanrenaud B (1978) Pre- and postweaning studies on development of obesity in $\mathrm{mdb} / \mathrm{mdb}$ mice. Am J Physiol 234: E568-E574

35. Crettaz M, Prentkin M, Zaninetti D, Jeanrenaud B (1980) Insulin resistance in soleus muscle from obese Zucker rats. Biochem $J$ 186: $525-534$

36. Grundleger ML, Godbole VY, Thenen SW (1980) Age-dependent development of insulin resistance of soleus muscle in genetically obese (ob/ob) mice. Am J Physiol 239: E363-E371

Received: 11 February 1983

and in revised form: 7 November 1983

Professor. R. G. Larkins

Department of Medicine

Royal Melbourne Hospital

Victoria 3050

Australia 